\title{
26. DATA REPORT: EOCENE TO UPPER MIOCENE CALCAREOUS NANNOFOSSIL STRATIGRAPHY'
}

\author{
Marie-Pierre Aubry ${ }^{2}$
}

\section{INTRODUCTION}

Leg 150 is the offshore part of a program specifically designed to test the assumptions and implications of sequence stratigraphy in relation to sea-level changes. One of the primary objectives of the cruise was to date seismic surfaces on the New Jersey Margin earlier described by Greenlee et al. (1992), through integration of bio-, magneto-, and chemostratigraphy. Calcareous nannofossil stratigraphy is a major asset in this endeavor because it constitutes the most favorable biostratigraphic tool for correlation between deep-sea and shallow-water deposits. This report serves to locate more precisely than in the Initial Reports (Mountain, Miller, Blum, et al., 1994) the position of some of the calcareous nannofossil zonal boundaries in the lower middle Eocene through upper Miocene sections recovered in six of the holes (Holes 902D, 903C, 903D, 904A, 905A, and 906A) drilled during Leg 150. Due to time constraints and to difficulty in dating some intervals as a result of secondary silicification, little new information is provided here regarding the upper Oligocene-lower Miocene interval.

\section{TECHNIQUES AND METHODS}

All zonal determinations are based on the examination of smear slides made from toothpick samples. The spacing between samples is highly variable, from one sample every $10 \mathrm{~cm}$ to one sample per section. Particular attention was given to intervals of uncertain calcareous nannofossil zonal position in Mountain, Miller, Blum, et al. (1994) and to intervals with contradictory biozonal assignments such as the upper Miocene diatom muds recovered from Cores 150-902D$21 \mathrm{X}$ to $23 \mathrm{X}$ (179.9-199.8 mbsf), 150-903A-41X to $46 \mathrm{X}$ (355.7$413.7 \mathrm{mbsf}$ ) and $150-904 \mathrm{~A}-19 \mathrm{H}$ to $20 \mathrm{H}$ (168-187 mbsf) in which planktonic foraminifers provided zonal assignments in disagreement with those derived from dinoflagellate cyst and diatom stratigraphies (Mountain, Miller, Blum, et al., 1994). The study of additional samples from the upper Oligocene and lower Miocene muds is currently in progress, and no complementary data on the calcareous nannofossil assemblages in these sediments is provided here. However, the biozonal assignments given by the author (referred to as MPA) in Mountain, Miller, Blum, et al. (1994) are confirmed.

The calcareous nannofossil biozonal scheme of Martini (1971) is used in this study. The original definition of the zones is followed except in the case of Zone NP25, the top of which is characterized herein by the highest occurrence (HO) of Reticulofenestra bisecta rather than by that of Helicosphaera recta, following the proposal of Berggren et al. (1985). Also, the NP15/NP16 zonal boundary is not precisely delineated due to the absence of Blackites gladius. Assemblages with Chiasmolithus solitus but without Nannotetrina fulgens are

'Mountain, G.S., Miller, K.G., Blum, P. Poag, C.W and Twichell, D.C. (Eds.), 1996. Proc. ODP, Sci. Results, 150: College Station, TX (Ocean Drilling Program).

${ }^{2}$ Laboratoire de Géologie du Quaternaire, CNRS, Case 907, 13288 Marseille Cedex, France. (Current address: Institut des Sciences de l'Evolution, Université de Montpellier II, Place Eugène Bataillon, 34095 Montpellier Cedex 05, France.) confidently assigned to Zone NP16 while sediments with Chiasmolithus gigas and $N$. fulgens are confidently assigned to Zone NP15. Intervening sediments are assigned to Zones NP15-NP16 undifferentiated. Following the recommendation of Martini (1976), and based on the recognition that the lowest occurrence (LO) of Sphenolithus pseudoradians, the marker of the base of Zone NP20 (Martini, 1971 ) is located in Zone NP16, Zones NP19 and NP20 are undifferentiated and the two zones constitute Zone NP19-20. The HO of Reticulofenestra reticulata is used to differentiate a lower and upper part in Zone NP19-20 (see discussion in Aubry, 1992).

Calcareous nannofossils are sparse to common in the upper Oligocene and Miocene clays and muds recovered from Leg 150. Most assemblages are of low diversity which resulted in uncertain zonal position of numerous levels. Calcareous nannofossils are generally abundant in the Eocene chalks but preservation varies from good to very poor, resulting in considerable changes in diversity between levels.

\section{CALCAREOUS NANNOFOSSIL STRATIGRAPHY}

\section{Hole 902D}

One hundred and twenty samples were taken from Cores 150902D-21X to $23 \mathrm{X}$ (170.9-199.8 mbsf) at intervals between 10 and 30 $\mathrm{cm}$. Most samples were barren or yielded very scarce and poorly preserved placoliths. Only a few samples yielded rare-to-common, poorly preserved calcareous nannofossils, and diversity was always extremely low. Sample 150-902D-20X-3, $30 \mathrm{~cm}$ (164.80 mbsf) yielded rare Coccolithus pelagicus. Sample 150-902D-20X-4, $60 \mathrm{~cm}(166.6$ mbsf), yielded scarce placoliths and cribriliths (Pontosphaera $\mathrm{sp}$.). Sample 150-902D-20X-CC, $12 \mathrm{~cm}$ (170.6 mbsf), yielded common Reticulofenestra gr. R. pseudoumbilicus and Coccolithus pelagicus, whereas Sample 150-902D-21X-3, $15 \mathrm{~cm}$ (174.05 mbsf), yielded rare $C$. pelagicus and $R$. pseudoumbilicus, and Sample 150-902D-21X-3, $60 \mathrm{~cm}$ (174.50 mbsf), yielded $R$. pseudoumbilicus and Sphenolithus sp. Samples 150-902D-21X-3, $110 \mathrm{~cm}$ (175 mbsf), 117-121 cm (175.10 mbsf), and Samples 150-902D-21X-4, $40 \mathrm{~cm}$ (175.8 mbsf), and $60 \mathrm{~cm}$ (176 mbsf), yielded very rare $R$. pseudoumbilicus. Sample $150-902 \mathrm{D}-23 \mathrm{X}-1,128 \mathrm{~cm}$ (191.48 mbsf), was the richest sample with $R$. pseudoumbilicus, C. pelagicus, and Discoaster variabilis. The scarcity of the calcareous nannofossils in these muds which yielded planktonic foraminifers is likely the result of secondary silicification.

Samples 150-902D-27X-1, 75-77 cm, and 84-86 cm (229.56 and 229.65 mbsf, respectively), 902D-27X-3, 10-12 cm (231.91 mbsf), 902D-28-5, 23-25 cm (244.65 mbsf), 902D-29X-1, 18-20 cm (248.30 mbsf), 902D-33X-3, 122-123 cm (290.82 mbsf), and 902D$33 \mathrm{X}-4,15-17 \mathrm{~cm}$ (291.25 mbsf), were also barren.

Hole 902D ended in upper Eocene calcareous nannofossil maris. The entire section from Sample 150-902D-74X-1, $74 \mathrm{~cm}(680.9$ mbsf), to $82 X-C C, 33 \mathrm{~cm}$ (736.4 mbsf), belongs to Zone NP19-20. The highest occurrence of Reticulofenestra reticulata is located between Samples 150-902D-75X-3, 50-53 cm (693.40 mbsf), and $75 \mathrm{X}-2,70-71 \mathrm{~cm}$ (692.10 mbsf). 


\section{Hole 903C}

The upper Eocene chalks recovered from Section 150-903C-52R$1,0 \mathrm{~cm}$, to $60 \mathrm{R}-\mathrm{CC}, 17 \mathrm{~cm}$ (1064.1-1150.0 mbsf), belong to Zones NP19-20, NP18, and NP16. It was initially thought that the section included a complete zonal succession from Zone NP16 to Zone NP19-20 with Zones NP17 and NP18 constituting two thin intervals. Examination of closely spaced samples indicate instead that Zone NP18 is unconformable with Zone NP16 and that abundant reworking occurs in the former zone. The rarity of representatives of the genus Chiasmolithus at many levels within Zone NP18, the generally poor preservation and low diversity, and the occurrence of $C$. grandis in greater number than placoliths of $C$. oamaruensis explains the difference between the shipboard interpretation (Mountain, Miller, Blum, et al., 1994) and this report. The NP16/NP18 zonal contact occurs between Samples 150-903C-58R-5, 90-91 cm, and 58R-5, 10$11 \mathrm{~cm}(1128-1127.20 \mathrm{mbsf})$. Reworked placoliths of $C$. grandis are common in particular in Samples 150-903C-58R-3, 107-112 cm (1125.20 mbsf), and in 58R-2, 40-41 cm (1123 mbsf). The NP18/ NP19-20 zonal boundary occurs between Samples 150-903C-56R$\mathrm{CC}$ (1112.40 mbsf) and 57R-1, $50 \mathrm{~cm}(1112.90 \mathrm{mbsf})$. The highest occurrence of $R$, reticulata is located between Samples 150-903C53R-5, 102-103 cm (1080.82 mbsf), and 53R-5, 20-21 cm (1080 mbsf).

\section{Hole 903D}

This hole was drilled to duplicate the lower middle-to-upper Oligocene interval that was discontinuously recovered in Hole 903C. The Oligocene/Miocene contact (NP25/[?] NN2) occurs between Samples 150-903D-24R-1, 70-71 cm, and 23R-CC (775.60-774.9 mbsf).

\section{Hole 904A}

Closely spaced samples were taken from Sections 150-904A$12 \mathrm{H}-1$ to $23 \mathrm{H}-3$ (104-207.5 mbsf). Age-significant calcareous nannofossil assemblages were expected to occur in these cores, at least in the lower part of the interval (Cores $19 \mathrm{H}$ to $23 \mathrm{H}$ ), based on the occurrence of age-diagnostic planktonic foraminifers. However, due to secondary silicification many levels were barren. At most other levels, assemblages of low diversity with poorly preserved nannofossils were not age diagnostic. The richest samples were from the following intervals: 150-904A-23H-3, 70-72 cm (206.7 mbsf), which yielded Reticulofenestra pseudoumbilicus, Discoaster sp. cf. D. variabilis, Discoaster sp. cf. D. challengeri, Discoaster sp. cf. D. sanmiguelensis, Discoaster sp. cf. D. bollii; 150-904A-21H-3, 76-78 cm (190.75 mbsf), which yielded $R$. pseudoumbilicus, Coccolithus pelagicus, Calcidiscus macintyrei, D. variabilis and Discoaster sp. cf. D. exilis; 150-904A-20H-3, 68-70 cm (182.20 mbsf), which yielded $R$. pseudoumbilicus, Coccolithus miopelagicus, Discoaster sp. cf. D. challengeri, $D$. variabilis, and C. macintyrei; 150-904A-19H-3, 90$92 \mathrm{~cm}$ (171.90 mbsf), which yielded $R$. pseudoumbilicus and D. challengeri. The occurrence of $C$. miopelagicus and $D$. challengeri in Sample $150-904 \mathrm{~A}-20 \mathrm{H}-3,90-92 \mathrm{~cm}$, is indicative of the NN7-NN8 zonal interval.

A thick Eocene section was recovered from Hole 904A between Sections $37 \mathrm{X}-4,20 \mathrm{~cm}$, and $62 \mathrm{X}-\mathrm{CC}, 40 \mathrm{~cm}(341.2-567.7 \mathrm{mbsf})$. Preservation is generally poor throughout the interval, and marker species are extremely rare at some levels. The interval from Sample 150-904A-37X-4, $20 \mathrm{~cm}$, to Sample 150-904A-44X-6, 70-71 cm (341.20-412 mbsf), belongs to Zone NP19-20. The HO of Reticulofenestra reticulata is located between Samples 150-904A-38X-CC and $40 \mathrm{X}-1,70-71 \mathrm{~cm}(355-365.8 \mathrm{mbs})$. The interval between Sample $150-904 \mathrm{~A}-45 \mathrm{X}-5,75-78 \mathrm{~cm}$ (420.15 mbsf), to $48 \mathrm{X}-6,70-71 \mathrm{~cm}$ (450.20 mbsf), is confidently assigned to Zone NP16, based on the occurrence of Chiasmolithus solitus and the absence of Nannotetrina fulgens. Neococcolithes dubius, Discoaster bifax, D. tani, D. tani nodifer, and Sphenolithus furcatolithoides further characterize this interval. The interval between Samples 150-904A-49X-1, 70-71 cm, and 50X-5, 70-71 cm (452.20-467.90 mbsf), is assigned to Zone NP15-NP16 undifferentiated based on the co-occurrence of Nannotetrina fulgens and Chiasmolithus solitus and the absence of Chiasmolithus gigas. The interval between Samples 150-904A-51X-2, $70-71 \mathrm{~cm}$, and $60 \mathrm{X}-1,25-26 \mathrm{~cm}(473.1-547.95 \mathrm{mbsf})$, is assigned to Zone NP15. Nannotetrina fulgens occurs throughout the interval which yields extremely poor preservation. The range of Chiasmolithus gigas - which characterizes Zone NP15b (= Zone CP13b of Okada and Bukry, 1980) - in this interval is uncertain at this time, although its HO is located between Samples 150-904A-51X-2, 70-71 $\mathrm{cm}$, and 50X-5, 70-71 cm (473.10-467.90 mbsf). The NP15/NP14 zonal boundary occurs between Samples 150-904A-60X-CC and $61 \mathrm{X}-1,70-71 \mathrm{~cm}$ ( 548.47 and $558 \mathrm{mbsf})$. The hole was terminated in Subzone NP14a characterized by the co-occurrence of Discoaster sublodoensis and $D$. lodoensis, and the absence of Rhabdosphaera inflata.

\section{Hole 905A}

The most important feature to determine regarding the lower middle to upper Miocene section recovered from this hole was whether the middle Miocene interval exhibited a normal stratigraphic succession or whether anomalous stratigraphic superposition occurred. Shipboard analysis revealed the occurrence of specimens of Catinaster coalitus (which LO defines the base of Zone NN8) below levels that were assigned to Zone NN6. However, diatom and dinocyst stratigraphies indicated a normal middle Miocene succession. A normal stratigraphic succession is confirmed by the examination of samples taken at intervals close to those from which C. coalitus was initially reported, between Sections 70X-1 and 94X-CC (626-867 mbsf). The anomalous occurrence of $C$. coalitus may have resulted from core contamination. In addition, the NN5/NN6 zonal boundary is located between Samples 150-905A-94X-3, 30-32 cm, and 94XCC (860.7-867 mbsf).

\section{Hole 906A}

The upper Oligocene/middle Miocene contact is located between Samples 150-906A-50X-CC and 51X-2, 70-72 cm (477.2 and 479.40 mbsf). Sample 150-906A-51X-1, 70-71 cm (477.9 mbsf), was barren.

Upper Eocene chalks were recovered between Core 150-906A$60 \mathrm{X}$ and Section 68X-CC (563.8-602.4 mbsf). They belong to Zone NP19-20. The highest occurrence of $R$. reticulata is located between Samples 150-906A-62X-CC and 64X-1, 20-21 cm (573.5 and $583.40 \mathrm{mbsf}$ ).

\section{ACKNOWLEDGMENTS}

I thank ODP for inviting me to participate to Leg 150. I thank K. von Salis, Timothy Bralower, and K. Miller for reviewing the paper and for editorial suggestions.

\section{REFERENCES}

Aubry, M.-P., 1992. Late Paleogene calcareous nannoplankton evolution: a tale of climatic deterioration. In Prothero, D.R., and Berggren, W.A. (Eds.), Eocene-Oligocene Climatic and Biotic Evolution: Princeton, NJ (Princeton Univ. Press), 272-309.

Berggren, W.A., Kent, D.V., and Flynn, J.J., 1985. Jurassic to Paleogene, Part 2. Paleogene geochronology and chronostratigraphy. In Snelling, 
N.J. (Ed.), The Chronology of the Geological Record. Geol. Soc. London Mem., 10:141-195.

Greenlee, S.M., Devlin, W.J., Miller, K.G., Mountain, G.S., and Flemings, P.B., 1992. Integrated sequence stratigraphy of Neogene deposits, New Jersey continental shelf and slope: comparison with the Exxon model. Geol. Soc. Am. Bull., 104:1403-1411.

Martini, E., 1971. Standard Tertiary and Quaternary calcareous nannoplankton zonation. In Farinacci, A. (Ed.), Proc. 2nd Int. Conf. Planktonic Microfossils Roma: Rome (Ed. Tecnosci.), 2:739-785.

1976. Cretaceous to Recent calcareous nannoplankton from the Central Pacific Ocean (DSDP Leg 33). In Schlanger, S.O., Jackson, E.D., et al., Init. Repts. DSDP, 33: Washington (U.S. Govt. Printing Office), 383-423.
Mountain, G.S., Miller, K.G., Blum, P., et al., 1994. Proc. ODP, Init. Repts., 150: College Station, TX (Ocean Drilling Program).

Okada, H., and Bukry, D., 1980. Supplementary modification and introduction of code numbers to the low-latitude coccolith biostratigraphic zonation (Bukry, 1973; 1975). Mar. Micropaleontol., 5:321-325.

Date of initial receipt: 20 March 1995

Date of acceptance: 5 July 1995

Ms 150SR-004 